\title{
Determining the Impact of the AM-Mycorrhizosphere on "Dwarf" Sunflower Zn Uptake and Soil-Zn Bioavailability
}

\author{
Patrick Audet $^{1,2}$ and Christiane Charest $^{1}$ \\ ${ }^{1}$ Department of Biology, Ottawa-Carleton Institute of Biology, University of Ottawa, 30 Marie Curie Priv., Ottawa, \\ ON, Canada K1N 6N5 \\ ${ }^{2}$ Centre for Mined Land Rehabilitation, Sustainable Minerals Institute, University of Queensland, St. Lucia Campus, Brisbane, \\ QLD, 4072, Australia
}

Correspondence should be addressed to Patrick Audet, paude086@uottawa.ca

Received 16 June 2010; Revised 13 August 2010; Accepted 15 October 2010

Academic Editor: Andrea Polle

Copyright (๑) 2010 P. Audet and C. Charest. This is an open access article distributed under the Creative Commons Attribution License, which permits unrestricted use, distribution, and reproduction in any medium, provided the original work is properly cited.

\begin{abstract}
An in vivo compartmental pot greenhouse experiment involving "dwarf" sunflower and an arbuscular mycorrhizal (AM) fungus was designed to assess the contribution of non-AM roots (rhizosphere), AM roots and extraradical hyphae (mycorrhizosphere), or strictly extraradical hyphae (hyphosphere) on plant growth, plant metal uptake, and soil parameters using the micronutrient zinc $(\mathrm{Zn})$ as a typical metal contaminant. We observed that, at high soil-Zn concentrations, the mycorrhizosphere treatments had lower $\mathrm{Zn}$ concentrations (especially in shoots and flowers) and a lower incidence of leaf chlorosis than the rhizosphere treatments. These phytoprotective effects are believed to be related to AM-induced biosorption processes that reduce soil metal bioavailability to delay the onset of plant metal toxicity. We also observed that the presence of extraradical hyphae causes a slight alkalinisation of the proximal soil environment whereas roots tended to acidify it, this having significant consequences toward metal bioavailability. Altogether, the AM symbiosis is considered to be a key component of ecosystem function involved in buffering plant growth conditions due to the processes of metal biosorption and hyphal alkalinisation which could contribute in enhancing the soil's resiliency.
\end{abstract}

\section{Introduction}

The arbuscular mycorrhizal (AM) symbiosis-a mutually beneficial association between the roots of most herbaceous plants and Glomeromycotan fungi [1]—is primarily recognized for increasing the mineral status of plants via the mycorrhizosphere (i.e., combined surface area of AM roots and extraradical hyphae). It has also been suggested that the mycorrhizosphere plays a key role in the regulation of soil metal bioavailability through biosorption processes, then contributing to the alleviation of plant metal toxicity and nutrient imbalances [2-6]. Recently, we proposed a conceptual model derived from meta-analytical findings depicting the impact of the AM symbiosis on plant metal uptake in relation to soil conditions ranging from low (trace) to high (toxic) metal exposure levels [7-9], a model we further investigated using an in vitro carrot root-organ culture system [10]. From these studies, we demonstrated that the AM fungi play a dual role in metal acquisition: first by increasing nutrient uptake at low metal exposure levels, and then lessening it at high levels through metal biosorption. Notably, in our in vitro study [10], we suggested that the "enhanced uptake" and "metal biosorption" processes occur independently in shaping plant metal uptake and, also, likely hold an important role in enhancing soil resiliency despite such metal toxicity conditions. To expand on these notions, we present here an in vivo compartmental pot growth system designed to assess the contribution of non-AM roots (rhizosphere), AM roots and extraradical hyphae (mycorrhizosphere), or strictly extraradical hyphae (hyphosphere) on plant growth and $\mathrm{Zn}$ uptake, soil $\mathrm{Zn}$ bioavailability, and soil-pH. The compartmental pot system was selected to isolate each of these "sphere environments" and subsequently determine their impact on various plant 
physiological and edaphic factors in relation to increasing soil metal exposure levels. In this regard, the "dwarf" sunflower cultivar Helianthus annuus L. var. Pacino and the AM fungus Glomus intraradices Schenck \& Smith (isolate DAOM-181602) were selected as suitable experimental organisms for the study and the essential micronutrient $\mathrm{Zn}$ as a typical metal contaminant which is known to reach toxic levels in the environment due to extensive fertilizer application, metal galvanization, and rubber vulcanization [11-13].

\section{Materials and Methods}

2.1. Experimental Design. Dwarf sunflower plants were grown from seeds (McKenzie Seeds, Brandon, MB, Canada) for 10 weeks in two-compartment pot systems containing a previously autoclaved, low mineral soil mixture (sand:potting soil, 1:1 v/v) which was then inoculated (or not) with fungal propagules of $G$. intraradices (Myke Pro Endo, Premier Tech, Rivière-du-Loup, QC, Canada). The fungal inoculum was integrated as a $3 \mathrm{~cm}$ thick substrate layer containing 15 propagules $\mathrm{g}^{-1}$ dry substrate $(200 \mathrm{~g}$ inoculum substrate dose having 2750-3000 total propagules per pot) in the AM treatments (mycorrhizosphere and hyphosphere plants), whereas the non-AM treatments (rhizosphere plants) received an equivalent volume of the same substrate without any propagules. Each experimental pot system (Figure 1(a)) was composed of a central compartment (7 L capacity) containing soil in which seeds were sown and a surrounding peripheral compartment (7 L capacity) containing the pre-sterilized soil treated with one of the four soil- $\mathrm{Zn}$ concentrations $(0,50,200$, $400 \mathrm{mg} \mathrm{Zn} \mathrm{kg}^{-1}$ dry soil), as determined from a previous study [14]. The two compartments were separated by either a $50 \mu \mathrm{m}$ or a $2000 \mu \mathrm{m}$ pore-size nylon filter bag (Industrial Filter Manufacturing Ltd., Penetanguishene, ON, Canada) which permitted either the proliferation of non-AM roots (Figure $1(\mathrm{~b})$-rhizosphere-2000 $\mu \mathrm{m}$ ), both AM roots and hyphae (Figure 1(c)—mycorrhizosphere-2000 $\mu \mathrm{m}$ ), or strictly extraradical hyphae (Figure 1(d)-hyphosphere$50 \mu \mathrm{m})$ into the peripheral compartment. In this regard, the $50 \mu \mathrm{m}$ filter was deemed large enough to allow fungal hyphae to proliferate into the peripheral compartment, but small enough to restrict roots, whereas the $2000 \mu \mathrm{m}$ filter was permeable to both. The soil- $\mathrm{Zn}$ treatments added to the peripheral compartment were achieved by weighing appropriate volumes of the pre-autoclaved soil, adding $\mathrm{Zn}$ from a $\mathrm{ZnSO}_{4} \cdot 7 \mathrm{H} 2 \mathrm{O}$ stock solution, homogenizing the mixture with an industrial mixer, and air-drying the soil. This soil pretreatment method was used to reduce the likelihood of metal diffusion from the peripheral compartment into the central compartment, compared to other point-source experimental amendment strategies [15]. The factorial design of the study (1 plant $s p . \times 3$ sphere treatments (non-AM rhizosphere, AM mycorrhizosphere, or AM hyphosphere) $\times 4$ soil- $\mathrm{Zn}$ concentrations $(0,50$, 200 , or $400 \mathrm{mg} \mathrm{kg}^{-1}$ DS) $\times 4$ reps) provided a total of 48 plants, 1 plant per pot. Four replicates of unseeded

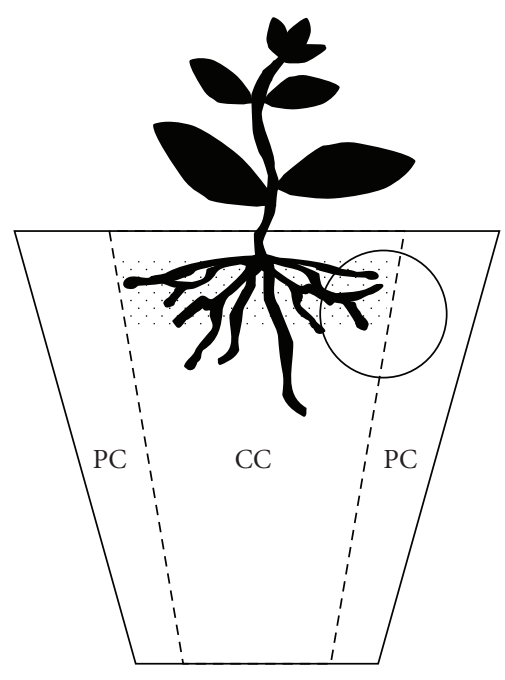

(a)

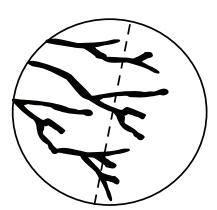

(b)

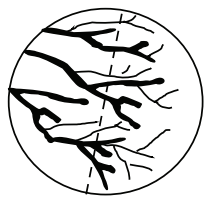

(c)

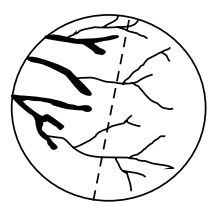

(d)
Figure 1: Schematization of the compartmental pot system (a) showing the proliferation of hyphae across the dividing filter. The inoculum (or control) substrate layer is shown. Seeds were sown in the central compartment (CC) while the soil- $\mathrm{Zn}$ treatments were incorporated in the surrounding peripheral compartment (PC) representing either the rhizosphere (b), mycorrhizosphere (c), or hyphosphere environments (d).

pots were also prepared for each of the soil- $\mathrm{Zn}$ treatments to compare the pre- and postexperimental soil- $\mathrm{Zn}$ bioavailability $\left(\mathrm{NaNO}_{3}\right.$ extractable) as well as the $\mathrm{pH}$ of the bare soil. The greenhouse conditions were maintained at $25^{\circ} \mathrm{C} / 23^{\circ} \mathrm{C}$ (day/night) with a 16 hour photoperiod under halogen lighting, an average daytime light intensity of $364.2 \mu \mathrm{mol} \mathrm{m} \mathrm{m}^{-2} \mathrm{~s}^{-1}$, and a $65 \%$ relative humidity using an Argus greenhouse control system (Argus Control Systems Ltd., White Rock, BC, Canada). Over the course of the experimental period, all plants as well as the unseeded pots were watered daily avoiding any leaching and fertilized biweekly ( $100 \mathrm{ml}$ per week) from weeks 4 to 10 using a low zinc Long-Ashton nutrient solution, pH 4.4 [16]: $2.0 \mathrm{mM} \mathrm{K}_{2} \mathrm{SO}_{4}, 4.0 \mathrm{mM} \mathrm{CaCl}_{2}$ anhydride, $1.5 \mathrm{mM} \quad \mathrm{MgSO}_{4} \cdot 7 \mathrm{H}_{2} \mathrm{O}, 1.5 \mathrm{mM} \quad \mathrm{NaH}_{2} \mathrm{PO}_{4} \cdot \mathrm{H}_{2} \mathrm{O}, \quad 5.0 \mu \mathrm{M}$ $\mathrm{NH}_{4} \mathrm{NO}_{3}, 0.01 \mathrm{mM} \mathrm{MnSO} \cdot 4 \mathrm{H}_{2} \mathrm{O}, 1.0 \mu \mathrm{M} \mathrm{CuSO} \cdot 5 \mathrm{H}_{2} \mathrm{O}$, $1.0 \mu \mathrm{M} \mathrm{ZnSO}_{4} \cdot 7 \mathrm{H}_{2} \mathrm{O}, 0.05 \mathrm{mM} \mathrm{H} \mathrm{H}_{3} \mathrm{BO}_{3}, \mathrm{NaCl} 0.09 \mathrm{mM}$, $0.5 \mu \mathrm{M} \mathrm{Na} \mathrm{MoO}_{4} \cdot 2 \mathrm{H}_{2} \mathrm{O}$, and $0.1 \mathrm{mM}$ EDTA-Fe.

2.2. Plant Physiological and Chemical Analyses. After the 10 -week growth period, plants were harvested, the roots clean-rinsed with tap water, and the length of shoots and number of healthy versus chlorotic (e.g., spotted) leaves recorded. Plants were then partitioned as flowers, shoots (e.g., leaves and stems), and roots, oven-dried at $70^{\circ} \mathrm{C}$ for $72 \mathrm{~h}$, and weighed separately. To determine plant- $\mathrm{Zn}$ concentrations, $100 \mathrm{mg}$ of dried flower, shoot, or root samples were ground and placed in acid-washed Teflon bombs (Nalgene, Rochester, NY, USA). Each sample was dissolved in $2 \mathrm{~mL}$ of $16 \mathrm{M} \mathrm{HNO}_{3}$, heated for $10 \mathrm{~h}$ in 
TABle 1: Pre-experimental soil characteristics.

\begin{tabular}{|c|c|c|c|}
\hline Parameter & Unit & \multicolumn{2}{|c|}{ Value (SE) } \\
\hline $\mathrm{P}^{*}$ & ppm & 20 & $(0.71)$ \\
\hline $\mathrm{K}^{\dagger}$ & ppm & 90.2 & $(0.86)$ \\
\hline $\mathrm{Mg}^{\dagger}$ & ppm & 214 & $(5.42)$ \\
\hline Organic Matter & $\%$ & 3.8 & $(0.25)$ \\
\hline $\mathrm{Na}^{\dagger}$ & ppm & 58.3 & $(7.87)$ \\
\hline $\mathrm{Ca}^{\dagger}$ & ppm & 1646 & $(250)$ \\
\hline CEC K & $\mathrm{meq} / 100 \mathrm{~g}^{\ddagger}$ & 0.2 & $(0)$ \\
\hline CEC Mg & $\mathrm{meq} / 100 \mathrm{~g}$ & 1.8 & $(0.05)$ \\
\hline CEC Ca & meq/100 g & 8.2 & $(1.26)$ \\
\hline CEC Na & meq/100 g & 0.3 & $(0.03)$ \\
\hline CEC Total & $\mathrm{meq} / 100 \mathrm{~g}$ & 10.6 & $(1.36)$ \\
\hline Base Saturation K & $\%$ & 2.3 & $(0.21)$ \\
\hline Base Saturation Mg & $\%$ & 17.6 & $(1.50)$ \\
\hline Base Saturation Ca & $\%$ & 78.1 & $(1.67)$ \\
\hline Base Saturation $\mathrm{Na}$ & $\%$ & 2 & $(0.50)$ \\
\hline
\end{tabular}

an $80^{\circ} \mathrm{C}$ water-bath, and diluted with $20 \mathrm{~mL}$ pure grade $\mathrm{H}_{2} \mathrm{O}$ (EMD Chemical Inc., Darmstadt, Germany). Five samples of apple leaves (Standard Reference Material \#1515) from the National Institute of Standards and Technology (NIST, Gaithersburg, MD, USA) and five blanks consisting solely of $\mathrm{HNO}_{3}$ and $\mathrm{H}_{2} \mathrm{O}$ were also prepared to ensure the quality and accuracy of the metal analyses. All plant samples were analyzed using Inductively Coupled Plasma Optical Emission Spectrometry (ICP OES-730-ES, Varian Inc., Palo Alto, CA, USA). The instrumental limit of detection calculated from the procedural blanks and reference material was $0.0036 \mu \mathrm{gg}^{-1}$.

2.3. Soil Chemical Analyses. The pre-experimental (e.g., prior to $\mathrm{Zn}$ treatment) soil characteristics (Table 1) were determined from five $10 \mathrm{~g}$ soil samples dissolved in $\mathrm{NaHCO}_{3}$ or $\mathrm{NH}_{4}$ acetate solutions and analyzed using Atomic Absorption Spectrometry (Accutest Laboratories, Ottawa, ON, Canada). Further to these analyses, soil samples for all treatments were also collected after the experimental period from both the central and peripheral compartments at harvest, and the unseeded pots sampled prior to and after the experimental growth period. The soil-pH of these samples was analyzed directly from $5 \mathrm{~g}$ of soil suspended in pure grade $\mathrm{H}_{2} \mathrm{O}$ with a soil : solution ratio of $1: 2.5(\mathrm{~m} / \mathrm{v})$ [17]. To determine soil-Zn concentrations, $5 \mathrm{~g}$ soil from each treatment were suspended in $0.1 \mathrm{M} \mathrm{NaNO}_{3}$ with a soil : solution ratio of $1: 2.5(\mathrm{~m} / \mathrm{v})$, filtered across an $11 \mu \mathrm{m}$ grade \#1 cellulose filter paper (Whatman Inc., Piscataway, NJ, USA), and analyzed with ICP OES [18]. Five samples of Buffalo River sediment (Standard Reference Material \#8704) from NIST along with five blanks consisting solely of $0.1 \mathrm{M}$ $\mathrm{NaNO}_{3}$ were also analyzed to ensure the quality and accuracy of the metal analysis. As with the plant tissue analysis, the instrumental limit of detection calculated from the procedural blanks and reference material was $0.0036 \mu \mathrm{g} \mathrm{g}^{-1}$.

2.4. Root Colonization Assay. At harvest, $2 \mathrm{~g}$ of fresh root samples from each replicate were carefully excised from the root-zone surrounding the tap-root and stained with an aniline blue $0.02 \%$ dye solution $(6.78 \mathrm{mM}$ aniline blue$500 \mathrm{ml}$ glycerol— $450 \mathrm{ml} \mathrm{H}_{2} \mathrm{Od}-50 \mathrm{ml} 1 \% \mathrm{HCl}$ ) [19]. Fifty $\sim 1-2 \mathrm{~cm}$ long root segments per replicate were mounted on slides and examined at 100x and 400x magnification using a compound microscope (CX41, Olympus Inc., Markham, ON, Canada). Samples of non-AM roots were also observed to ensure their non-mycorrhizal status. Mycorrhizal colonization was estimated by determining the \% frequency of fungal structures and \% length of root colonization as evidenced by the presence of hyphae, vesicles and arbuscules $[19,20]$. The equations for the $\%$ frequency $(1)$ and $\%$ length of root colonization (2) are defined as

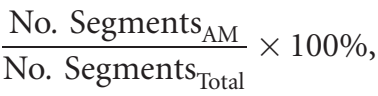

$$
\begin{aligned}
& \frac{\text { Root Length }_{\mathrm{AM}}}{\text { Root Length }_{\mathrm{Total}}} \times 100 \% \text {, }
\end{aligned}
$$

Together, these respective indicators provide insight into the relative distribution and intensity of the AM root colonization [21].

2.5. Statistical Analyses. One- and two-way Analyses of Variance (ANOVA) with Bonferonni and Scheffé studentized range tests were performed for mean comparisons of plant metal uptake, plant growth, and root colonization data whereas univariate regression models were used to calculate the slopes of soil-pH and soil-Zn data [22]. Analyses of Co-Variance (ANCOVA) were performed on the soil-pH and soil- $\mathrm{Zn}$ data to compare the slopes and intercepts of the regression equations between the treatments. The Kolmogorov-Schmirnoff and Levene's tests were used to verify the normality of distribution and the homogeneity of residual variance. The data were Log-transformed as required to meet the assumptions of each parametric analysis. All of the Fisher statistics $(F)$, coefficients of determination $\left(r^{2}\right)$, degrees of freedom $(d f)$, and $P$-value estimates were calculated using S-Plus 8.0 statistical software (Insightful Corp., Seattle, WA, USA).

\section{Results}

Significant differences were observed in flower, shoot, and root $\mathrm{Zn}$ concentrations between the hyphosphere, mycorrhizosphere, and rhizosphere treatments with increasing soil$\mathrm{Zn}$ addition (Figures 2(a), 2(b), and 2(c)). Although the plant $\mathrm{Zn}$ concentrations did not vary among the treatments at the low soil-Zn levels, the rhizosphere treatments had $20 \%$ to $40 \%$ higher $\mathrm{Zn}$ concentrations in their tissues than the mycorrhizosphere treatments, and $55 \%$ to $75 \%$ higher concentrations than the hyphosphere treatments at both the 200 and 400 soil-Zn concentrations. As for plant growth 


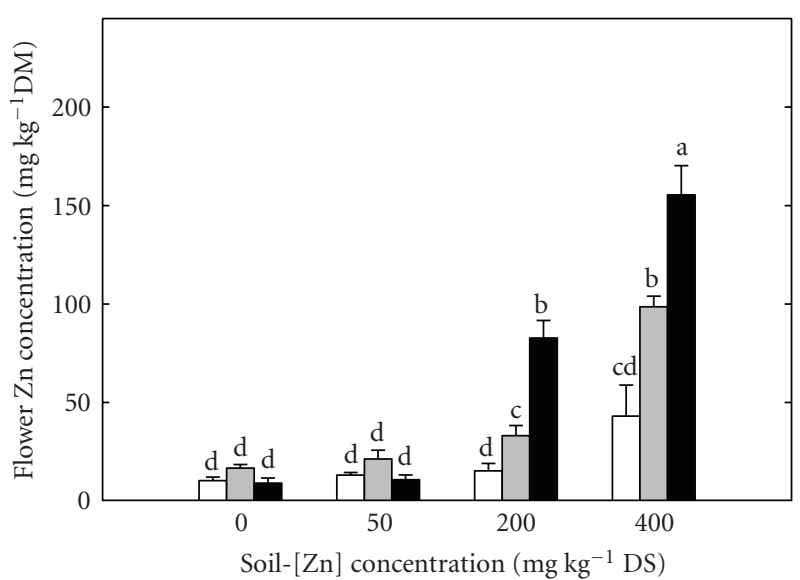

(a) Flowers

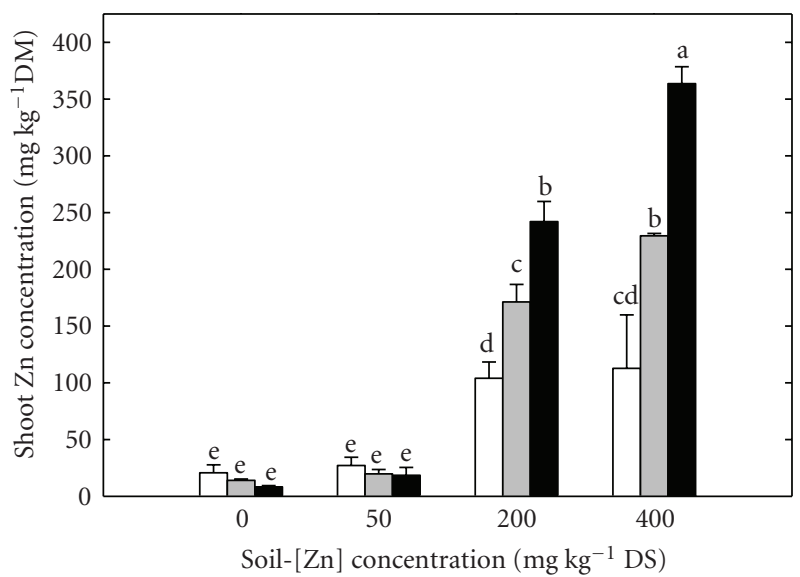

(b) Shoots

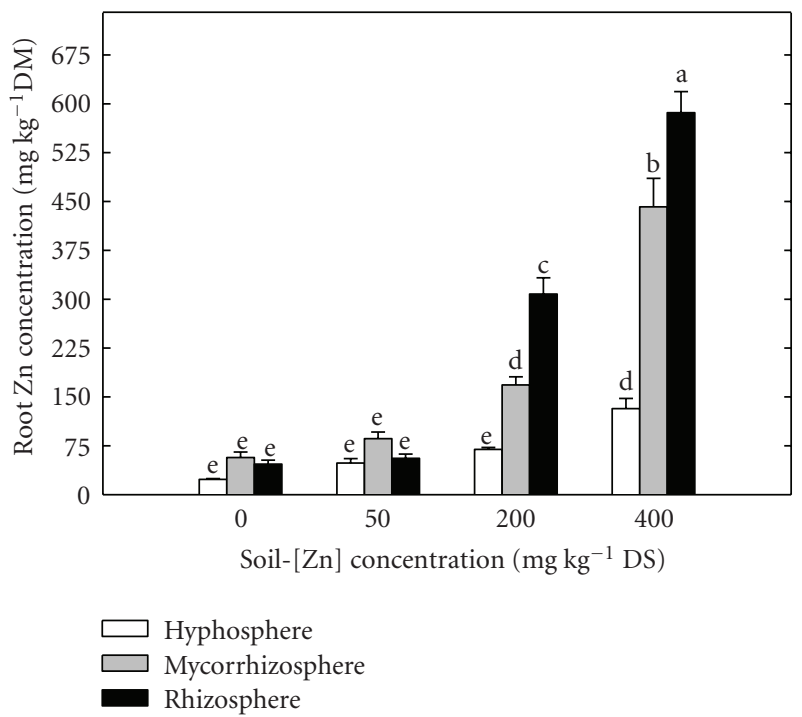

(c) Roots

Figure 2: Flower (a), shoot (b), and root Zn concentrations (c). Means $(n=4)$ and standard errors for the rhizosphere (black), mycorrhizosphere (grey), and hyphosphere (white) treatments are shown. Shared letters designate treatments that are not significantly different according to ANOVA coupled with Bonferonni and Scheffé mean comparison tests $(P<.05)$.

(Table 2), the rhizosphere treatments generally had greater flower, shoot, and root dry masses and longer shoots than mycorrhizosphere and especially hyphosphere treatments; however, these plant growth parameters did not show any particular trends in relation to soil-Zn amendment. Still, as a symptom of metal toxicity, rhizosphere treatments had increasingly higher percentages (up to $45.6 \%$ ) of chlorotic leaves compared to mycorrhizosphere (up to $36.0 \%$ ) and hyphosphere treatments (up to 7.6\%). Moreover, roots collected in the peripheral compartment of rhizosphere and mycorrhizosphere treatments had similar dry masses; meanwhile, it was noted that no roots were found in this compartment among the hyphosphere treatments. All roots from the mycorrhizosphere and hyphosphere treatments were shown to be well colonized as evidenced by the presence of hyphae, vesicles, and arbuscules (Table 3). More specifically, a higher \% frequency of hyphae than vesicles and arbuscules was observed among all the treatments, but a slight decline in \% hyphal-root length colonized in relation with increasing soil-Zn levels. In addition, rhizosphere treatments were confirmed to be nonmycorrhizal.

The soil-Zn concentrations were measured in the peripheral (Figure 3(a)) and central compartments (Figure 3(b)) and regression models calculated for each treatment (Table 4). The pre-experimental soil-Zn concentration in the peripheral compartment indicated a linear increase in relation with increasing soil- $\mathrm{Zn}$ amendment reaching up to $404.1 \mathrm{mg} \mathrm{kg}^{-1}$ dry soil. The postexperimental soils indicated polynomial (e.g., hyperbolic) profiles in the descending order of unseeded bare-soil ( $272.5 \mathrm{mg} \mathrm{kg}^{-1}$ dry soil), hyphosphere (263.4), mycorrhizosphere (247.2), and rhizosphere treatments (199.2). By contrast, there were no significant trends (e.g., no slope) for soil-Zn in the central compartment with values ranging between 0.01 and $0.07 \mathrm{mg} \mathrm{kg}^{-1}$ 


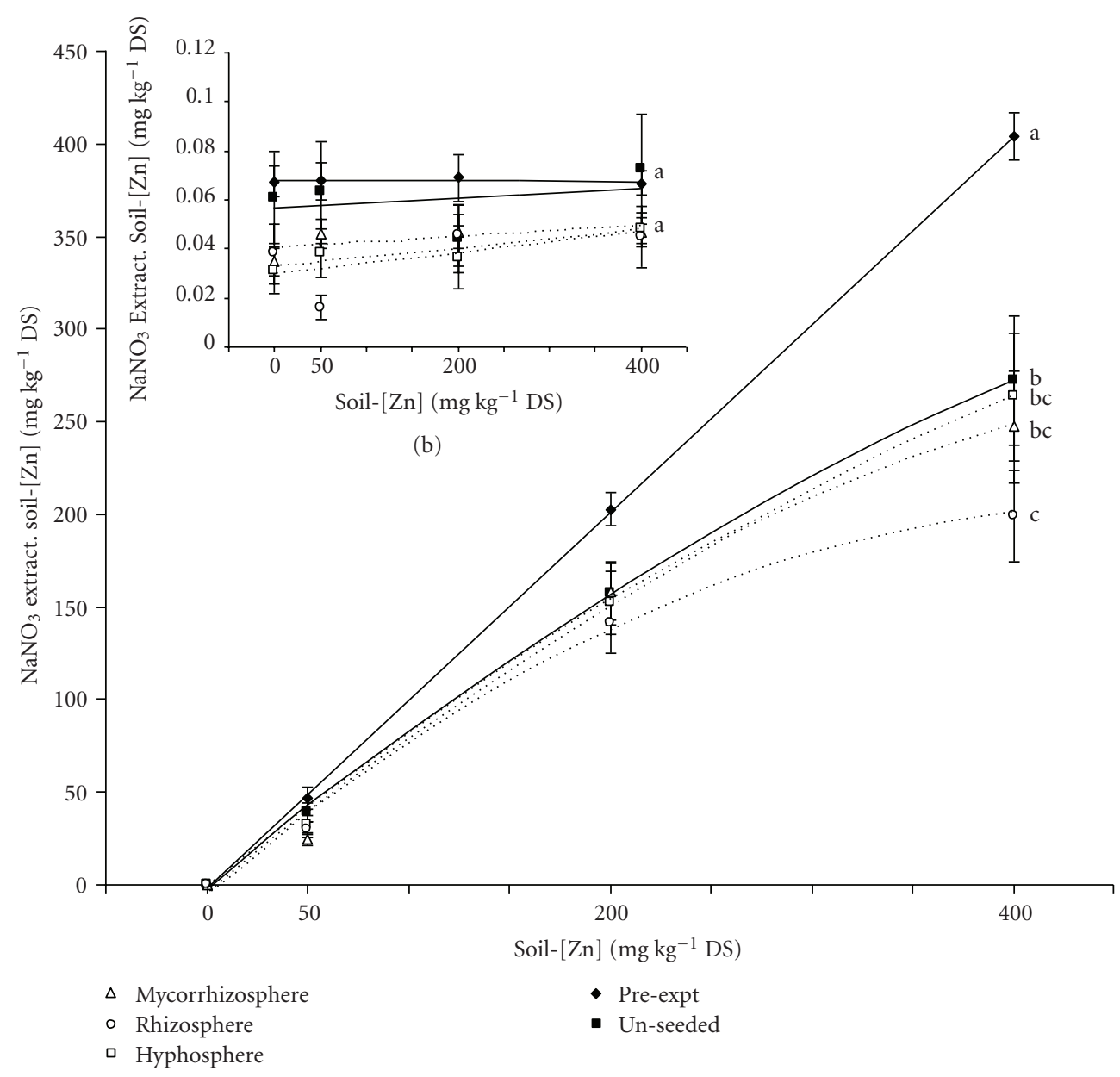

(a)

FIGURE 3: Soil-Zn concentrations measured in the peripheral (a) and central compartments (b). Means $(n=4)$ and standard errors for the pre-experimental unseeded (black diamond), post-experimental unseeded (black square), hyphosphere (white square), mycorrhizosphere (white triangle), and rhizosphere (white circle) treatments are shown. Shared letters designate regression equations having slopes that are not significantly different according to ANCOVA $(P<.05)$.

dry soil. The soil-pH was also measured in the peripheral (Figure 4(a)) and central compartments (Figure 4(b)) and regression models calculated for each treatment (Table 5). Unlike the soil-Zn concentrations, the pre-experimental soil$\mathrm{pH}$ in the peripheral compartment indicated a linear decline from 6.30 to 5.53 with increasing soil-Zn levels. Meanwhile, the postexperimental soils also indicated significant decreases in $\mathrm{pH}$, but profiles having polynomial trends in the descending order of unseeded bare-soil (from 5.80 to 5.28), hyphosphere (from 5.69 to 5.26), mycorrhizosphere (from 5.59 to 5.23), and rhizosphere treatments (from 5.52 to 5.17). Although there were no significant trends (e.g., no slope) for soil-pH in the central compartment, the range values were gradually lower in the order of pre-experimental unseeded bare-soil (6.32-6.42), postexperimental unseeded bare-soil (5.77-5.83), hyphosphere (5.57-5.62), mycorrhizosphere (5.59-5.61), and then rhizosphere treatments (5.56$5.60)$.

\section{Discussion}

Consistent with our conceptual model regarding the impact of AM symbiosis on plant growth and metal uptake $[8,10]$, the $\mathrm{Zn}$ concentrations of plants from the mycorrhizosphere treatments were generally lower than rhizosphere treatments at the highest soil-Zn levels which resulted in AM plants having a lower incidence of metal toxicity (e.g., leaf chlorosis). These findings are in line with other studies that detected lower $\mathrm{Cd}, \mathrm{Zn}$, and $\mathrm{Pb}$ uptake and an improved growth status in various AM (Glomus sp.) versus non-AM plants [23-26]. We attribute such enhanced metal-stress tolerance with AM-induced biosorption processes, including hyphal metal-binding and metal-ligand precipitation [27-29], that reduce metal bioavailability in the mycorrhizosphere to decrease plant metal uptake $[3,5,6]$. Correspondingly, further studies have shown that metals can be taken up and sequestered in fungal tissues instead of being transferred to 


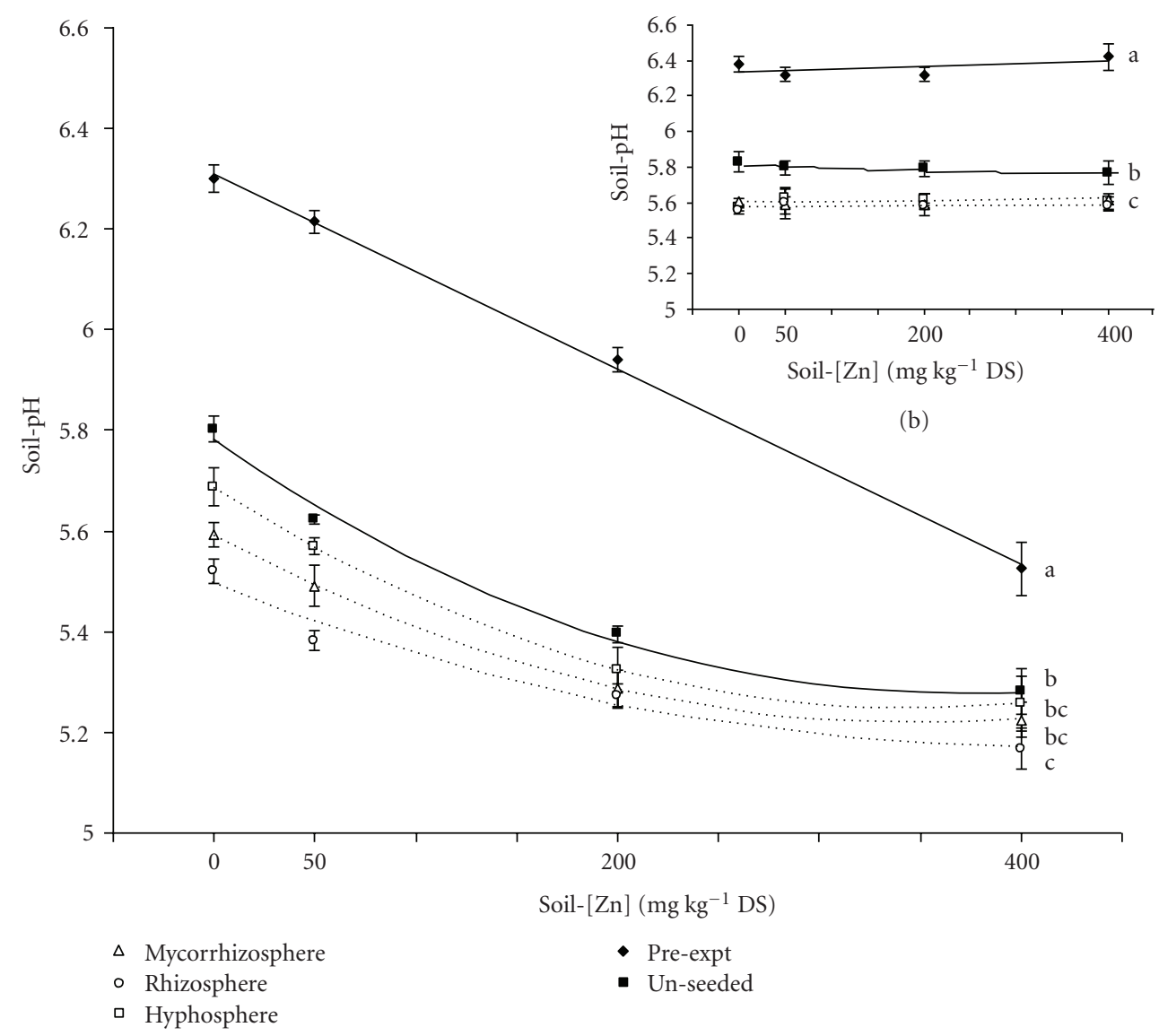

(a)

FIGURE 4: Soil-pH measured in the peripheral (a) and central compartments (b). Means $(n=4)$ and standard errors for the pre-experimental unseeded (black diamond), post-experimental unseeded (black square), hyphosphere (white square), mycorrhizosphere (white triangle), and rhizosphere (white circle) treatments are shown. Shared letters designate regression equations having slopes that are not significantly different according to ANCOVA $(P<.05)$.

roots $[4,30,31]$, thereby reducing cellular oxidative stress and delaying the onset of plant metal toxicity [32]. For these reasons, mycorrhizal biosorption and hyphal sequestration are considered to be important stress avoidance strategies that protect host plants in complement to their intrinsic detoxification mechanisms, such as metallotheinin and phytochelatin metabolisms [33]. In addition to comparing the metal uptake profiles of AM versus non-AM plants, our two-compartment pot system was specifically designed to determine the relative contributions of extraradical hyphae to host plant $\mathrm{Zn}$ uptake. Accordingly, in spite of having significantly lower $\mathrm{Zn}$ concentration levels than the rhizosphere and mycorrhizosphere treatments, plants of the hyphosphere treatments still had increasingly higher $\mathrm{Zn}$ concentrations even at the highest soil- $\mathrm{Zn}$ treatments. In agreement with our in vitro study [10], this finding indicates that hyphal metal uptake and its transfer to roots can contribute in increasing plant metal status despite the biosorption effect which typically reduces it, as in the case of other metals such as $\mathrm{Ni}, \mathrm{Cr}, \mathrm{Cs}$, and $\mathrm{Pb}$ [34-37]. For this reason, we believe that the enhanced uptake and biosorption processes occur independently: the first increasing the absorptive capacity of roots and the second regulating the bioavailability of metals in soils. Thus, it is their combined effects that shape the host plant's metal uptake profile.

Contrary to our conceptual model, we did not detect any significant differences in plant $\mathrm{Zn}$ uptake nor any major symptoms of nutrient deficiency among plants of the 0control and 50 soil- $\mathrm{Zn}$ levels. In this case, these soil- $\mathrm{Zn}$ treatments likely did not impose any perceptible nutrient deficiency stress or growth limitations which can otherwise lead plants to invest more in AM symbiosis to supplement their nutritional status $[38,39]$. This can be attributed to the pre-experimental soil-Zn levels and fertilization regimes used in our study which likely provided sufficient $\mathrm{Zn}$ for an optimal plant growth among these treatments. As such, further experimental investigation may be needed to verify this facet of our proposed model which proposed that the AM symbiosis would enhance plant metal uptake to circumvent deficiency conditions. Still, we did observe the general trends of slightly lower dry masses, fewer leaves, and shorter shoots among the mycorrhizosphere and especially the hyphosphere 
TABLE 2: Plant growth parameters.

\begin{tabular}{|c|c|c|c|c|c|c|c|c|}
\hline \multirow{2}{*}{$\begin{array}{l}\text { Soil-Zn } \\
\left(\mathrm{mg} \mathrm{kg} \mathrm{kg}^{-1} \mathrm{DS}\right)\end{array}$} & \multirow{2}{*}{ Sphere treatments } & \multicolumn{4}{|c|}{ Dry mass $(\mathrm{g})$} & \multicolumn{2}{|c|}{ Leaves } & \multirow{2}{*}{$\begin{array}{l}\text { Shoot } \\
\text { height } \\
(\mathrm{cm})\end{array}$} \\
\hline & & Flowers & Shoots & $\begin{array}{c}\text { Roots- } \\
\text { CC† }\end{array}$ & $\begin{array}{c}\text { Roots- } \\
\text { PC } \neq\end{array}$ & Total no. & $\begin{array}{c}\% \\
\text { Chlorotic }\end{array}$ & \\
\hline \multirow{3}{*}{0} & Hyphosphere & $\begin{array}{c}0.86 \\
(0.09)^{\mathrm{b}}\end{array}$ & $\begin{array}{c}1.57 \\
(0.43)\end{array}$ & $\begin{array}{c}0.77 \\
(0.03)^{\mathrm{b}}\end{array}$ & $\begin{array}{c}0 \\
(0.0)^{\mathrm{b}}\end{array}$ & $\begin{array}{l}14.5 \\
(1.19)\end{array}$ & $\begin{array}{c}0.76 \\
(0.51)^{\mathrm{c}}\end{array}$ & $\begin{array}{c}16.3 \\
(1.84)^{\mathrm{b}}\end{array}$ \\
\hline & Mycorrhizosphere & $\begin{array}{c}1.65 \\
(0.04)^{\mathrm{a}}\end{array}$ & $\begin{array}{c}1.98 \\
(0.51)\end{array}$ & $\begin{array}{c}1.05 \\
(0.21)^{\mathrm{a}}\end{array}$ & $\begin{array}{c}0.19 \\
(0.07)^{\mathrm{a}}\end{array}$ & $\begin{array}{l}16.25 \\
(0.25)\end{array}$ & $\begin{array}{c}1.52 \\
(0.78)^{\mathrm{c}}\end{array}$ & $\begin{array}{c}18.3 \\
(2.24)^{\mathrm{ab}}\end{array}$ \\
\hline & Rhizosphere & $\begin{array}{c}1.76 \\
(0.19)^{\mathrm{a}}\end{array}$ & $\begin{array}{c}2.01 \\
(0.33)\end{array}$ & $\begin{array}{c}0.98 \\
(0.12)^{\mathrm{a}}\end{array}$ & $\begin{array}{c}0.20 \\
(0.04)^{\mathrm{a}}\end{array}$ & $\begin{array}{l}18.5 \\
(2.21)\end{array}$ & $\begin{array}{c}0.00 \\
(0.00)^{\mathrm{d}}\end{array}$ & $\begin{array}{l}23.5 \\
(2.9)^{\mathrm{a}}\end{array}$ \\
\hline \multirow{3}{*}{50} & Hyphosphere & $\begin{array}{c}0.82 \\
(0.14)^{\mathrm{b}}\end{array}$ & $\begin{array}{c}1.68 \\
(0.11)\end{array}$ & $\begin{array}{c}0.89 \\
(0.06)^{\mathrm{ab}}\end{array}$ & $\begin{array}{c}0 \\
(0.0)^{\mathrm{b}}\end{array}$ & $\begin{array}{l}14.3 \\
(0.85)\end{array}$ & $\begin{array}{c}3.13 \\
(2.00)^{\mathrm{b}}\end{array}$ & $\begin{array}{l}17.9 \\
(1.07)^{\mathrm{b}}\end{array}$ \\
\hline & Mycorrhizosphere & $\begin{array}{c}1.58 \\
(0.12)^{\mathrm{a}}\end{array}$ & $\begin{array}{c}2.15 \\
(0.32)\end{array}$ & $\begin{array}{c}1.00 \\
(0.07)^{\mathrm{a}}\end{array}$ & $\begin{array}{c}0.19 \\
(0.03)^{\mathrm{a}}\end{array}$ & $\begin{array}{l}17.0 \\
(1.14)\end{array}$ & $\begin{array}{c}4.75 \\
(1.88)^{\mathrm{b}}\end{array}$ & $\begin{array}{r}21.89 \\
(1.88)^{\mathrm{ab}}\end{array}$ \\
\hline & Rhizosphere & $\begin{array}{c}1.76 \\
(0.20)^{\mathrm{a}}\end{array}$ & $\begin{array}{c}2.24 \\
(0.34)\end{array}$ & $\begin{array}{c}0.96 \\
(0.04)^{\mathrm{a}}\end{array}$ & $\begin{array}{c}0.24 \\
(0.06)^{\mathrm{a}}\end{array}$ & $\begin{array}{c}17.5 \\
(2.30)\end{array}$ & $\begin{array}{c}8.13 \\
(4.18)^{\mathrm{b}}\end{array}$ & $\begin{array}{l}23.75 \\
(2.26)^{\mathrm{a}}\end{array}$ \\
\hline \multirow{3}{*}{200} & Hyphosphere & $\begin{array}{c}1.01 \\
(0.12)^{\mathrm{b}}\end{array}$ & $\begin{array}{c}1.79 \\
(0.28)\end{array}$ & $\begin{array}{c}0.68 \\
(0.09)^{\mathrm{b}}\end{array}$ & $\begin{array}{c}0 \\
(0.0)^{\mathrm{b}}\end{array}$ & $\begin{array}{c}13.8 \\
(0.62)\end{array}$ & $\begin{array}{c}3.13 \\
(2.00)^{\mathrm{b}}\end{array}$ & $\begin{array}{r}16.13 \\
(1.98)^{\mathrm{b}}\end{array}$ \\
\hline & Mycorrhizosphere & $\begin{array}{c}1.35 \\
(0.33)^{\mathrm{a}}\end{array}$ & $\begin{array}{c}2.23 \\
(0.17)\end{array}$ & $\begin{array}{c}0.94 \\
(0.17)^{\mathrm{a}}\end{array}$ & $\begin{array}{c}0.18 \\
(0.02)^{\mathrm{a}}\end{array}$ & $\begin{array}{c}16.5 \\
(0.64)\end{array}$ & $\begin{array}{c}27.1 \\
(6.60)^{\mathrm{a}}\end{array}$ & $\begin{array}{c}19.1 \\
(2.56)^{\mathrm{ab}}\end{array}$ \\
\hline & Rhizosphere & $\begin{array}{c}1.50 \\
(0.17)^{\mathrm{a}}\end{array}$ & $\begin{array}{l}2.08 \\
(0.09)\end{array}$ & $\begin{array}{c}0.93 \\
(0.04)^{\mathrm{a}}\end{array}$ & $\begin{array}{c}0.18 \\
(0.04)^{\mathrm{a}}\end{array}$ & $\begin{array}{l}17.0 \\
(2.12)\end{array}$ & $\begin{array}{c}40.1 \\
(11.6)^{\mathrm{a}}\end{array}$ & $\begin{array}{c}22.0 \\
(2.38)^{\mathrm{a}}\end{array}$ \\
\hline \multirow{3}{*}{400} & Hyphosphere & $\begin{array}{c}0.74 \\
(0.08)^{\mathrm{b}}\end{array}$ & $\begin{array}{c}1.45 \\
(0.16)\end{array}$ & $\begin{array}{c}0.61 \\
(0.11)^{\mathrm{b}}\end{array}$ & $\begin{array}{c}0 \\
(0.0)^{\mathrm{b}}\end{array}$ & $\begin{array}{l}13.5 \\
(1.83)\end{array}$ & $\begin{array}{c}7.60 \\
(4.63)^{\mathrm{b}}\end{array}$ & $\begin{array}{c}15.5 \\
(1.04)^{\mathrm{b}}\end{array}$ \\
\hline & Mycorrhizosphere & $\begin{array}{c}1.51 \\
(0.29)^{\mathrm{a}}\end{array}$ & $\begin{array}{c}2.06 \\
(0.15)\end{array}$ & $\begin{array}{c}0.72 \\
(0.06)^{\mathrm{b}}\end{array}$ & $\begin{array}{c}0.24 \\
(0.05)^{\mathrm{a}}\end{array}$ & $\begin{array}{c}13.8 \\
(1.03)\end{array}$ & $\begin{array}{c}36.0 \\
(10.7)^{\mathrm{a}}\end{array}$ & $\begin{array}{c}17.8 \\
(1.53)^{\mathrm{b}}\end{array}$ \\
\hline & Rhizosphere & $\begin{array}{c}1.41 \\
(0.31)^{\mathrm{a}} \\
\end{array}$ & $\begin{array}{c}1.76 \\
(0.26) \\
\end{array}$ & $\begin{array}{c}0.68 \\
(0.10)^{\mathrm{b}} \\
\end{array}$ & $\begin{array}{c}0.19 \\
(0.02)^{\mathrm{a}} \\
\end{array}$ & $\begin{array}{c}14.5 \\
(0.96) \\
\end{array}$ & $\begin{array}{c}45.6 \\
(10.9)^{\mathrm{a}} \\
\end{array}$ & $\begin{array}{r}21.75 \\
(2.67)^{\mathrm{a}} \\
\end{array}$ \\
\hline \multicolumn{9}{|c|}{$F$-values and levels of significance } \\
\hline & Soil-Zn (Zn) & $0.63^{\mathrm{ns}}$ & $1.31^{\mathrm{ns}}$ & $3.63^{*}$ & $0.26^{\mathrm{ns}}$ & $2.05^{\mathrm{ns}}$ & $78.5^{* * *}$ & $1.41^{\mathrm{ns}}$ \\
\hline & $\begin{array}{c}\text { Sphere treatments } \\
\text { (S) }\end{array}$ & $16.4^{* * *}$ & $0.14^{\mathrm{ns}}$ & $3.33^{*}$ & $37.6^{* * *}$ & $1.42^{\mathrm{ns}}$ & $63.2^{* * *}$ & $3.5^{*}$ \\
\hline & ZnxS & $0.73^{\mathrm{ns}}$ & $1.27^{\mathrm{ns}}$ & $0.85^{\mathrm{ns}}$ & $0.95^{\mathrm{ns}}$ & $0.70^{\text {ns }}$ & $18.3^{* * *}$ & $0.54^{\mathrm{ns}}$ \\
\hline & Block & $1.28^{\mathrm{ns}}$ & $2.04^{\mathrm{ns}}$ & $0.85^{\mathrm{ns}}$ & $0.11^{\mathrm{ns}}$ & $0.58^{\mathrm{ns}}$ & $0.35^{\mathrm{ns}}$ & $1.41^{\mathrm{ns}}$ \\
\hline
\end{tabular}

Means $(n=4)$ and SE (inside parentheses) are shown.

Shared letters within each column designate treatments that are not significantly different according to Bonferonni and Scheffé mean comparison tests. †Central Compartment; $\ddagger$ Peripheral Compartment.

"ns" nonsignificant; ${ }^{*} P<.05 ;{ }^{* *} P<.01 ;{ }^{* * *} P<.001$.

treatments compared to the rhizosphere treatments, which may have resulted from the metabolic cost of maintaining the symbiotic association through the transfer of plant carbohydrates to the AM fungus [40]. Corresponding with the considerable levels of AM root colonization reported here (e.g., as evidenced by the high frequency and distribution of fungal hyphae, arbuscules, and vesicles), the reduction in AM than non-AM plant biomass could be associated with the host plants' carbon allocation in developing the mycorrhizospheric infrastructure. Alternatively, this tendency could also be attributed, in part, to the design of our compartmental pot systems, especially among the hyphosphere treatments. In this case, the $50 \mu \mathrm{m}$ filter bags themselves may have limited the "rootable" volume of the hyphosphere plants to then reduce their overall growth [41]. Nevertheless, the similar levels of AM root colonization and abundance of all fungal structures among both the mycorrhizosphere and hyphosphere treatments would suggest that the symbiotic investment was similar between these treatments, and that the effect of our experimental design on plant growth and metal uptake was negligible.

As for the soil conditions, the addition of $\mathrm{Zn}$ in the form of $\mathrm{ZnSO}_{4}$ caused a linear decrease of the pre-experimental soil-pH which was likely prompted by the proportional increase of $\mathrm{SO}_{4}^{2-}$ in the soil solution [24]. Furthermore, the daily watering and fertilization regimes also affected the soil conditions such that the soil-pH and soil-Zn levels all showed polynomial rather than linear profiles. Over time, the influx 
TABLE 3: AM root colonization.

\begin{tabular}{|c|c|c|c|c|c|c|c|}
\hline \multirow{3}{*}{$\begin{array}{l}\text { Soil-Zn } \\
\left(\mathrm{mg} \mathrm{kg}^{-1} \mathrm{DS}\right)\end{array}$} & \multirow{3}{*}{ Sphere treatments } & \multicolumn{6}{|c|}{ Fungal structures } \\
\hline & & \multicolumn{2}{|c|}{ Hyphae } & \multicolumn{2}{|c|}{ Vesicles } & \multicolumn{2}{|c|}{ Arbuscules } \\
\hline & & $\begin{array}{c}\% \\
\text { Frequency }\end{array}$ & $\begin{array}{l}\% \text { Root } \\
\text { length }\end{array}$ & $\begin{array}{c}\% \\
\text { Frequency }\end{array}$ & $\begin{array}{l}\% \text { Root } \\
\text { Length }\end{array}$ & $\begin{array}{c}\% \\
\text { Frequency }\end{array}$ & $\begin{array}{l}\% \text { Root } \\
\text { length }\end{array}$ \\
\hline \multirow{2}{*}{0} & Hyphosphere & $28.5(1.7)$ & $50.5(10.9)^{\mathrm{a}}$ & $21.0(3.1)$ & $36.5(8.8)$ & $21.5(2.9)$ & $26.0(1.8)^{\mathrm{a}}$ \\
\hline & Mycorrhizosphere & $29.0(6.2)$ & $57.5(4.8)^{\mathrm{a}}$ & $25.5(7.3)$ & $29.0(3.3)$ & $17.5(3.2)$ & $30.0(2.0)^{\mathrm{a}}$ \\
\hline \multirow{2}{*}{50} & Hyphosphere & $34.0(8.6)$ & $56.3(2.8)^{\mathrm{a}}$ & $22.0(2.6)$ & $27.5(6.3)$ & $27.5(3.3)$ & $32.5(2.5)^{\mathrm{a}}$ \\
\hline & Mycorrhizosphere & $26.5(5.6)$ & $30.0(4.1)^{\mathrm{b}}$ & $23.5(3.0)$ & $30.0(4.1)$ & $13.8(4.4)$ & $25.0(2.9)^{\mathrm{a}}$ \\
\hline \multirow{2}{*}{200} & Hyphosphere & $22.0(5.2)$ & $29.5(10.0)^{\mathrm{ab}}$ & $19.5(5.6)$ & $29.5(5.0)$ & $20.5(5.1)$ & $28.5(1.5)^{\mathrm{a}}$ \\
\hline & Mycorrhizosphere & $32.5(3.8)$ & $21.5(14.5)^{\mathrm{ab}}$ & $9.5(3.4)$ & $21.5(6.5)$ & $18.5(3.0)$ & $16.3(2.4)^{\mathrm{b}}$ \\
\hline \multirow{2}{*}{400} & Hyphosphere & $30.5(7.7)$ & $35.0(6.5)^{\mathrm{ab}}$ & $22.5(4.6)$ & $35.0(6.5)$ & $19.5(3.9)$ & $25.0(6.5)^{\mathrm{ab}}$ \\
\hline & Mycorrhizosphere & $33.5(5.2)$ & $30.5(10.5)^{\mathrm{ab}}$ & $17.5(4.9)$ & $20.5(3.9)$ & $24.5(5.7)$ & $31.3(3.1)^{\mathrm{a}}$ \\
\hline \multicolumn{8}{|c|}{$F$-values and levels of significance } \\
\hline & Soil-Zn (Zn) & $0.94^{\mathrm{ns}}$ & $0.28^{\mathrm{ns}}$ & $2.13^{\text {ns }}$ & $0.64^{\mathrm{ns}}$ & $0.17^{\mathrm{ns}}$ & $1.55^{\mathrm{ns}}$ \\
\hline & $\begin{array}{c}\text { Sphere Treatments } \\
\text { (S) }\end{array}$ & $0.04^{\mathrm{ns}}$ & $0.55^{\mathrm{ns}}$ & $0.67^{\mathrm{ns}}$ & $3.31^{\mathrm{ns}}$ & $1.62^{\mathrm{ns}}$ & $0.98^{\mathrm{ns}}$ \\
\hline & ZnxS & $0.27^{\mathrm{ns}}$ & $3.16^{*}$ & $1.41^{\mathrm{ns}}$ & $0.86^{\mathrm{ns}}$ & $1.78^{\mathrm{ns}}$ & $3.47^{*}$ \\
\hline & Block & $0.17^{\mathrm{ns}}$ & 1.63 & $3.99 *$ & $2.44^{\mathrm{ns}}$ & $0.83^{\mathrm{ns}}$ & $0.13^{\mathrm{ns}}$ \\
\hline
\end{tabular}

Means $(n=4)$ and SE (inside parentheses) are shown.

Shared letters within each column designate treatments that are not significantly different according to Bonferonni and Scheffé mean comparison tests.

"ns" nonsignificant; * $P<.05$.

TABLE 4: Regression models for soil-Zn as a function of soil-Zn treatment.

\begin{tabular}{|c|c|c|c|c|c|c|c|c|}
\hline Parameter & Compartment & Analysis & Treatment & $f(x)$ & $F$ & $r^{2}$ & $d f$ & $P$ \\
\hline \multirow{10}{*}{ Soil-Zn } & \multirow{5}{*}{ Peripheral } & Pre-Experimental & Unseeded & $1.015 x-1.45$ & 5060 & 0.99 & 1,14 & $<10^{-3}$ \\
\hline & & \multirow{4}{*}{ Post-Experimental } & Unseeded & $\begin{array}{c}-\left(4.7^{e}-4\right) x^{2}+ \\
0.89 x-1.46\end{array}$ & 2573 & 0.99 & 1,14 & $<10^{-3}$ \\
\hline & & & Hyphosphere & $\begin{array}{c}-\left(4.7^{e}-4\right) x^{2}+ \\
0.86 x-3.76\end{array}$ & 618.8 & 0.98 & 2,13 & $<10^{-3}$ \\
\hline & & & Mycorrhizosphere & $\begin{array}{c}-\left(7.5^{e}-4\right) x^{2}+ \\
0.97 x-8.48\end{array}$ & 475.9 & 0.98 & 2,13 & $<10^{-3}$ \\
\hline & & & Rhizosphere & $\begin{array}{c}-0.001 x^{2}+0.91 x- \\
5.20\end{array}$ & 249.7 & 0.97 & 2,13 & $<10^{-3}$ \\
\hline & \multirow{5}{*}{ Central } & \multirow[t]{2}{*}{ Pre-Experimental } & Unseeded & $\left(1.0^{e}-7\right) x+0.06$ & 0.10 & 0.01 & 1,14 & .75 \\
\hline & & & Unseeded & $\left(1.0^{e}-7\right) x+0.04$ & 1.29 & 0.08 & 1,14 & .27 \\
\hline & & \multirow{3}{*}{ Post-Experimental } & Hyphosphere & $\left(1.0^{e}-7\right) x+0.03$ & 1.46 & 0.09 & 1,14 & .25 \\
\hline & & & Mycorrhizosphere & $\left(1.0^{e}-7\right) x+0.03$ & 1.52 & 0.10 & 1,14 & .24 \\
\hline & & & Rhizosphere & $\left(1.0^{e}-7\right) x+0.07$ & 0.01 & 0.01 & 1,14 & .96 \\
\hline
\end{tabular}

Polynomial equations $[f(x)]$, Fisher values $[F]$, coefficients of determination $\left[r^{2}\right]$, degrees of freedom $[d f]$, and estimates of $P$-value are shown.

of $\mathrm{SO}_{4}^{2-}$ and $\mathrm{H}^{+} / \mathrm{H}_{3} \mathrm{O}^{+}$ions in the soil solution associated with the addition of $\mathrm{Zn}$ and water alters the soil's redox equilibrium and impacts the solubility of metal nutrients [42-45]: a process referred to as "metal ageing" [46]. Such inputs and metal ageing processes can detrimentally influence the soil's metal-binding capacity, resulting in an increased rate of metal leaching [45, 47, 48]. For these reasons, it is noteworthy that the presence of roots and (or) extraradical hyphae further affected soil conditions in a way that the soil-pH was increasingly more acidic and the soil-Zn bioavailability was gradually lower in the order of hyphosphere, mycorrhizosphere, and rhizosphere treatments. These tendencies are primarily attributable to the different rates of $\mathrm{Zn}$ uptake between the treatments and the subsequently different soil-Zn depletion zones. Notwithstanding, the exudation of organic chelators by roots and (or) extraradical hyphae may also have played a part in shaping the edaphic conditions, as in the case of 
TABLE 5: Regression models for soil-pH as a function of soil- $\mathrm{Zn}$ treatment.

\begin{tabular}{|c|c|c|c|c|c|c|c|c|}
\hline Parameter & Compartment & Analysis & Treatment & $f(x)$ & $F$ & $r^{2}$ & $d f$ & $P$ \\
\hline \multirow{10}{*}{ Soil-pH } & \multirow{5}{*}{ Peripheral } & Pre-Experimental & Unseeded & $-0.002 x+6.31$ & 65.5 & 0.82 & 1,14 & $<10^{-3}$ \\
\hline & & \multirow{4}{*}{ Post-Experimental } & Unseeded & $\begin{array}{c}\left(3.8^{e}-6\right) x^{2}- \\
\left(2.8^{e}-6\right) x+5.78\end{array}$ & 205.1 & 0.97 & 2,13 & $<10^{-3}$ \\
\hline & & & Hyphosphere & $\begin{array}{c}\left(3.7^{e}-6\right) x^{2}-\left(2.6^{e}-\right. \\
6) x+5.71\end{array}$ & 205.1 & 0.95 & 2,13 & $<10^{-3}$ \\
\hline & & & Mycorrhizosphere & $\begin{array}{l}\left(2.8^{e}-6\right) x^{2}- \\
0.0021 x+5.63\end{array}$ & 76.5 & 0.92 & 2,13 & $<10^{-3}$ \\
\hline & & & Rhizosphere & $\begin{array}{c}\left(1.9^{e}-6\right) x^{2}- \\
\left(1.6^{e}-6\right) x+5.49\end{array}$ & 87.9 & 0.93 & 2,13 & $<10^{-3}$ \\
\hline & \multirow{5}{*}{ Central } & Pre-Experimental & Unseeded & $\left(1.0^{e}-4\right) x+6.34$ & 1.72 & 0.11 & 1,14 & .21 \\
\hline & & \multirow{4}{*}{ Post-Experimental } & Unseeded & $\left(1.0^{e}-4\right) x+5.78$ & 1.65 & 0.10 & 1,14 & .25 \\
\hline & & & Hyphosphere & $\left(3.7^{e}-5\right) x+5.59$ & 0.30 & 0.02 & 1,14 & .59 \\
\hline & & & Mycorrhizosphere & $\left(3.2^{e}-5\right) x+5.59$ & 0.24 & 0.02 & 1,14 & .64 \\
\hline & & & Rhizosphere & $\left(2.8^{e}-5\right) x+5.57$ & 0.15 & 0.01 & 1,14 & .71 \\
\hline
\end{tabular}

Polynomial equations $[f(x)]$, Fisher values $[F]$, coefficients of determination $\left[r^{2}\right]$, degrees of freedom $[d f]$, and estimates of $P$-value are shown.

phosphorus and nitrogen acquisition by mycorrhizae [4953]. From these studies, it has been suggested that the extraradical hyphae can induce the moderate alkalinisation of their growth substrate in relation to $\mathrm{P}$ and $\mathrm{N}$ uptake whereas roots tend to acidify it. This could be relevant to our proposed conceptual model of AM-plant metal uptake since the process of hyphal alkalisation could favour metal biosorption to contribute in reducing metal bioavailability, unlike root acidification that may facilitate leaching and then increase metal solubility. Accordingly, we consider it intriguing for future experimental investigations to examine these mechanisms more closely (e.g., metal biosorption and hyphal alkalinisation) within the context of plant metal uptake in order to further elucidate the impact of the extraradical hyphae on soil metal bioavailability. Altogether, when taking into account the impact of the AM symbiosis in stabilizing the soil matrix and enhancing its water and nutrient retention capacity [54-56], the mycorrhizosphere should play a key role in enhancing the soil's resiliency in relation to metal stress conditions ranging from trace to toxicity exposure levels.

In conclusion and in line with our hypothetical model, we demonstrated that the AM symbiosis plays an important part in shaping host-plant Zn uptake, particularly by reducing plant tissue $\mathrm{Zn}$ concentrations at high exposure levels and thereby delaying the onset of $\mathrm{Zn}$ toxicity in shoots and flowers compared to non-AM plants. Accordingly, we also suggested that the mycorrhizosphere plays an equally important role in shaping the soil environment via biosorption processes and other AM-induced chemical changes which contribute in enhancing the soil's resiliency. As such, we consider the AM symbiosis to be an essential component of extrinsic stress tolerance and a key factor of ecosystem function. Meanwhile, we also consider our model depicting the impact of the AM symbiosis on plant and soil systems to be a relevant tool in environmental remediation practices by conceptually determining the fate of metal contaminants in relation with the activities of plants and soil microorganisms.

\section{Abbreviations}

AM: $\quad$ Arbuscular mycorrhiza

ICP OES: Inductively coupled plasma optical emission spectrometry

Zn: $\quad$ Zinc.

\section{Acknowledgments}

Special thanks are given by the authors to Dr. Andrea Polle (Editor) and the anonymous evaluators for their insightful review of this manuscript. The authors also thank Dr. N. DeSilva (Department of Earth Sciences, University of Ottawa) for ICP OES analyses. This study was made possible by a Canada Graduate Scholarship to P. Audet and a Discovery Grant to C. Charest from the Natural Science and Engineering Research Council of Canada.

\section{References}

[1] A. Schüßler, D. Schwarzott, and C. Walker, "A new fungal phylum, the Glomeromycota: phylogeny and evolution," Mycological Research, vol. 105, no. 12, pp. 1413-1421, 2001.

[2] P. Christie, X. Li, and B. Chen, "Arbuscular mycorrhiza can depress translocation of zinc to shoots of host plants in soils moderately polluted with zinc," Plant and Soil, vol. 261, no. 1-2, pp. 209-217, 2004.

[3] P. Jeffries, S. Gianinazzi, S. Perotto, K. Turnau, and J.-M. Barea, "The contribution of arbuscular mycorrhizal fungi in sustainable maintenance of plant health and soil fertility," Biology and Fertility of Soils, vol. 37, no. 1, pp. 1-16, 2003.

[4] E. J. Joner, R. Briones, and C. Leyval, "Metal-binding capacity of arbuscular mycorrhizal mycelium," Plant and Soil, vol. 226, no. 2, pp. 227-234, 2000.

[5] C. Leyval, K. Turnau, and K. Haselwandter, "Effect of heavy metal pollution on mycorrhizal colonization and function: physiological, ecological and applied aspects," Mycorrhiza, vol. 7, no. 3, pp. 139-153, 1997.

[6] A. A. Meharg, "The mechanistic basis of interactions between mycorrhizal associations and toxic metal cations," Mycological Research, vol. 107, no. 11, pp. 1253-1265, 2003. 
[7] P. Audet and C. Charest, "Heavy metal phytoremediation from a meta-analytical perspective," Environmental Pollution, vol. 147, no. 1, pp. 231-237, 2007.

[8] P. Audet and C. Charest, "Dynamics of arbuscular mycorrhizal symbiosis in heavy metal phytoremediation: meta-analytical and conceptual perspectives," Environmental Pollution, vol. 147, no. 3, pp. 609-614, 2007.

[9] P. Audet and C. Charest, "Allocation plasticity and plant-metal partitioning: meta-analytical perspectives in phytoremediation," Environmental Pollution, vol. 156, no. 2, pp. 290-296, 2008.

[10] P. Audet and C. Charest, "Contribution of arbuscular mycorrhizal symbiosis to in vitro root metal uptake: from trace to toxic metal conditions," Botany, vol. 87, no. 10, pp. 913-921, 2009.

[11] D. G. Barceloux, "Zinc," Journal of Toxicology-Clinical Toxicology, vol. 37, no. 2, pp. 279-292, 1999.

[12] R. L. Chaney, "Zinc phytotoxicity," in Zinc in Soils and Plants, A. D. Robson, Ed., pp. 135-150, Kluwer Academic Publishers, Dodrecht, The Netherlands, 1993.

[13] T. R. Cavagnaro, "The role of arbuscular mycorrhizas in improving plant zinc nutrition under low soil zinc concentrations: a review," Plant and Soil, vol. 304, no. 1-2, pp. 315-325, 2008.

[14] P. Audet and C. Charest, "Effects of AM colonization on "wild tobacco" plants grown in zinc-contaminated soil," Mycorrhiza, vol. 16, no. 4, pp. 277-283, 2006.

[15] B. J. Reid, G. L. Northcott, K. C. Jones, and K. T. Semple, "Evaluation of spiking procedures for the introduction of poorly water soluble contaminants into soil," Environmental Science and Technology, vol. 32, no. 20, pp. 3224-3227, 1998.

[16] G. S. Smith, C. M. Johnston, and I. S. Cornforth, "Comparison of nutrient solutions for growth of plants in sand culture," New Phytologist, vol. 94, no. 4, pp. 537-548, 1983.

[17] W. H. Hendershot, H. Lalande, and M. Duquette, "Soil reaction and exchangeable acidity," in Soil Sampling and Methods of Analysis, M. R. Carter and E. G. Gregorich, Eds., pp. 173-178, CRC Press, Boca Raton, Fla, USA, 2nd edition, 2008.

[18] K. Wenger, S. K. Gupta, G. Furrer, and R. Schulin, "Zinc extraction potential of two common crop plants, Nicotiana tabacum and Zea mays," Plant and Soil, vol. 242, no. 2, pp. 217-225, 2002.

[19] Y. Dalpé, "Vesicular-arbuscular mycorrhizae," in Soil Sampling and Methods of Analysis, M. R. Carter, Ed., pp. 287-301, CRC Press, Boca Raton, Fla, USA, 3rd edition, 1993.

[20] T. P. McGonigle, M. H. Miller, D. G. Evans, G. L. Fairchild, and J. A. Swan, "A new method which gives an objective measure of colonization of roots by vesicular-arbuscular mycorrhizal fungi," New Phytologist, vol. 115, no. 3, pp. 495-501, 1990.

[21] M. F. Allen, "Modeling arbuscular mycorrhizal infection: is \% infection an appropriate variable?" Mycorrhiza, vol. 10, no. 5, pp. 255-258, 2001.

[22] J. H. Zar, Biostatistical Analysis, Prentice-Hall, Upper-Saddle River, NJ, USA, 3rd edition, 1999.

[23] Y. L. Bi, X. L. Li, and P. Christie, "Influence of early stages of arbuscular mycorrhiza on uptake of zinc and phosphorus by red clover from a low-phosphorus soil amended with zinc and phosphorus," Chemosphere, vol. 50, no. 6, pp. 831-837, 2003.

[24] X. Li and P. Christie, "Changes in soil solution $\mathrm{Zn}$ and $\mathrm{pH}$ and uptake of $\mathrm{Zn}$ by arbuscular mycorrhizal red clover in $\mathrm{Zn}$ contaminated soil," Chemosphere, vol. 42, no. 2, pp. 201-207, 2000.
[25] F. Rivera-Becerril, C. Calantzis, K. Turnau et al., "Cadmium accumulation and buffering of cadmium-induced stress by arbuscular mycorrhiza in three Pisum sativum L. genotypes," Journal of Experimental Botany, vol. 53, no. 371, pp. 11771185, 2002.

[26] Y. Zhu, P. Christie, and A. S. Laidlaw, "Uptake of Zn by arbuscular mycorrhizal white clover from $\mathrm{Zn}$-contaminated soil," Chemosphere, vol. 42, no. 2, pp. 193-199, 2001.

[27] G. M. Gadd, "Interactions of fungi with toxic metals," New Phytologist, vol. 124, no. 1, pp. 25-60, 1993.

[28] U. Galli, H. Schuepp, and C. Brunold, "Heavy metal binding by mycorrhizal fungi," Physiologia Plantarum, vol. 92, no. 2, pp. 364-368, 1994.

[29] C. Gonzalez-Chavez, J. D’Haen, J. Vangronsveld, and J. C. Dodd, "Copper sorption and accumulation by the extraradical mycelium of different Glomus spp. (arbuscular mycorrhizal fungi) isolated from the same polluted soil," Plant and Soil, vol. 240, no. 2, pp. 287-297, 2002.

[30] B. Chen, P. Christie, and X. Li, "A modified glass bead compartment cultivation system for studies on nutrient and trace metal uptake by arbuscular mycorrhiza," Chemosphere, vol. 42, no. 2, pp. 185-192, 2001.

[31] M. González-Guerrero, C. Cano, C. Azcón-Aguilar, and N. Ferrol, "GintMT1 encodes a functional metallothionein in Glomus intraradices that responds to oxidative stress," Mycorrhiza, vol. 17, no. 4, pp. 327-335, 2007.

[32] A. Schützendübel and A. Polle, "Plant responses to abiotic stresses: heavy metal-induced oxidative stress and protection by mycorrhization," Journal of Experimental Botany, vol. 53, no. 372, pp. 1351-1365, 2002.

[33] C. Cobbett and P. Goldsbrough, "Phytochelatins and metallothioneins: roles in heavy metal detoxification and homeostasis," Annual Review of Plant Biology, vol. 53, pp. 159-182, 2002.

[34] K. Ker and C. Charest, "Nickel remediation by AM-colonized sunflower," Mycorrhiza, vol. 20, no. 6, pp. 399-406, 2010.

[35] S. Declerck, H. Dupré de Boulois, C. Bivort, and B. Delvaux, "Extraradical mycelium of the arbuscular mycorrhizal fungus Glomus lamellosum can take up, accumulate and translocate radiocaesium under root-organ culture conditions," Environmental Microbiology, vol. 5, no. 6, pp. 510-516, 2003.

[36] A. Hovsepyan and S. Greipsson, "Effect of arbuscular mycorrhizal fungi on phytoextraction by corn (Zea mays) of leadcontaminated soil," International Journal of Phytoremediation, vol. 6, no. 4, pp. 305-321, 2004.

[37] F. T. Davies Jr., J. D. Puryear, R. J. Newton, J. N. Egilla, and J. A. Saraiva Grossi, "Mycorrhizal fungi enhance accumulation and tolerance of chromium in sunflower (Helianthus annuus)," Journal of Plant Physiology, vol. 158, no. 6, pp. 777-786, 2001.

[38] H. Marschener, "Role of root growth, arbuscular mycorrhiza, and root exudates for the efficiency in nutrient acquisition," Field Crops Research, vol. 56, no. 1-2, pp. 203-207, 1998.

[39] S. E. Smith and V. Gianinazzi-Pearson, "Physiological interactions between symbionts in vesicular-arbuscular mycorrhizal plants," Annual Review of Plant Physiology, vol. 39, pp. 221244, 1988.

[40] A. H. Fitter, "Costs and benefits of mycorrhizas: implications for functioning under natural conditions," Experientia, vol. 47, no. 4, pp. 350-355, 1991.

[41] P. Audet and C. Charest, "Identification of constraining experimental design factors in mycorrhizal pot-growth studies," Journal of Botany, vol. 2010, Article ID 718013, 6 pages, 2010.

[42] M. C. Chuan, G. Y. Shu, and J. C. Liu, "Solubility of heavy metals in a contaminated soil: effects of redox potential and 
pH," Water, Air, and Soil Pollution, vol. 90, no. 3-4, pp. 543$556,1996$.

[43] C. E. Martínez and H. L. Motto, "Solubility of lead, zinc and copper added to mineral soils," Environmental Pollution, vol. 107, no. 1, pp. 153-158, 2000.

[44] S. M. Ross, "Retention, transformation and mobility of toxic metals in soils," in Toxic Metals in Soil-Plant Systems, S. M. Ross, Ed., pp. 63-152, John Wiley \& Sons, New York, NY, USA, 1994.

[45] F. M. Tack, O. W. J. J. Callewaert, and M. G. Verloo, "Metal solubility as a function of $\mathrm{pH}$ in a contaminated, dredged sediment affected by oxidation," Environmental Pollution, vol. 91, no. 2, pp. 199-208, 1996.

[46] K. Lock and C. R. Janssen, "Influence of aging on metal availability in soils," Reviews of Environmental Contamination and Toxicology, vol. 178, pp. 1-21, 2003.

[47] R. Apak, "Adsorption of heavy metal ions on soil surfaces and similar substances," in Encyclopedia of Surface and Colloid Science, A. T. Hubbard, Ed., pp. 385-417, Dekker Encyclopedias, New York, NY, USA, 2002.

[48] H. B. Bradl, "Adsorption of heavy metal ions on soils and soils constituents," Journal of Colloid and Interface Science, vol. 277, no. 1, pp. 1-18, 2004.

[49] B. Bago, H. Vierheilig, Y. Piché, and C. Azcón-Aguilar, "Nitrate depletion and $\mathrm{pH}$ changes induced by the extraradical mycelium of the arbuscular mycorrhizal fungus Glomus intraradices grown in monoxenic culture," New Phytologist, vol. 133, no. 2, pp. 273-280, 1996.

[50] G. Eckhard, H. Marschner, and I. Jakobsen, "The role of arbuscular mycorrhizal fungi in uptake of phosphorus and nitrogen from soil," Critical Reviews in Biotechnology, vol. 15, pp. 257-270, 1995.

[51] T. S. Gahoonia and N. E. Nielsen, "The effects of rootinduced $\mathrm{pH}$ changes on the depletion of inorganic and organic phosphorus in the rhizosphere," Plant and Soil, vol. 143, no. 2, pp. 185-191, 1992.

[52] X. Li, E. George, and H. Marschner, "Phosphorus depletion and $\mathrm{pH}$ decrease at the root-soil and hyphae-soil interfaces of VA mycorrhizal white clover fertilized with ammonium," New Phytologist, vol. 119, no. 3, pp. 397-404, 1991.

[53] G. Rufyikiri, S. Declerck, and Y. Thiry, "Comparison of ${ }^{233} \mathrm{U}$ and ${ }^{33} \mathrm{P}$ uptake and translocation by the arbuscular mycorrhizal fungus Glomus intraradices in root organ culture conditions," Mycorrhiza, vol. 14, no. 3, pp. 203-207, 2004.

[54] R. M. Miller and J. D. Jastrow, "Hierarchy of root and mycorrhizal fungal interactions with soil aggregation," Soil Biology and Biochemistry, vol. 22, no. 5, pp. 579-584, 1990.

[55] R. M. Augé, A. J. W. Stodola, J. E. Tims, and A. M. Saxton, "Moisture retention properties of a mycorrhizal soil," Plant and Soil, vol. 230, no. 1, pp. 87-97, 2001.

[56] J. S. Piotrowski, T. Denich, J. N. Klironomos, J. M. Graham, and M. C. Rillig, "The effects of arbuscular mycorrhizas on soil aggregation depend on the interaction between plant and fungal species," New Phytologist, vol. 164, no. 2, pp. 365-373, 2004. 

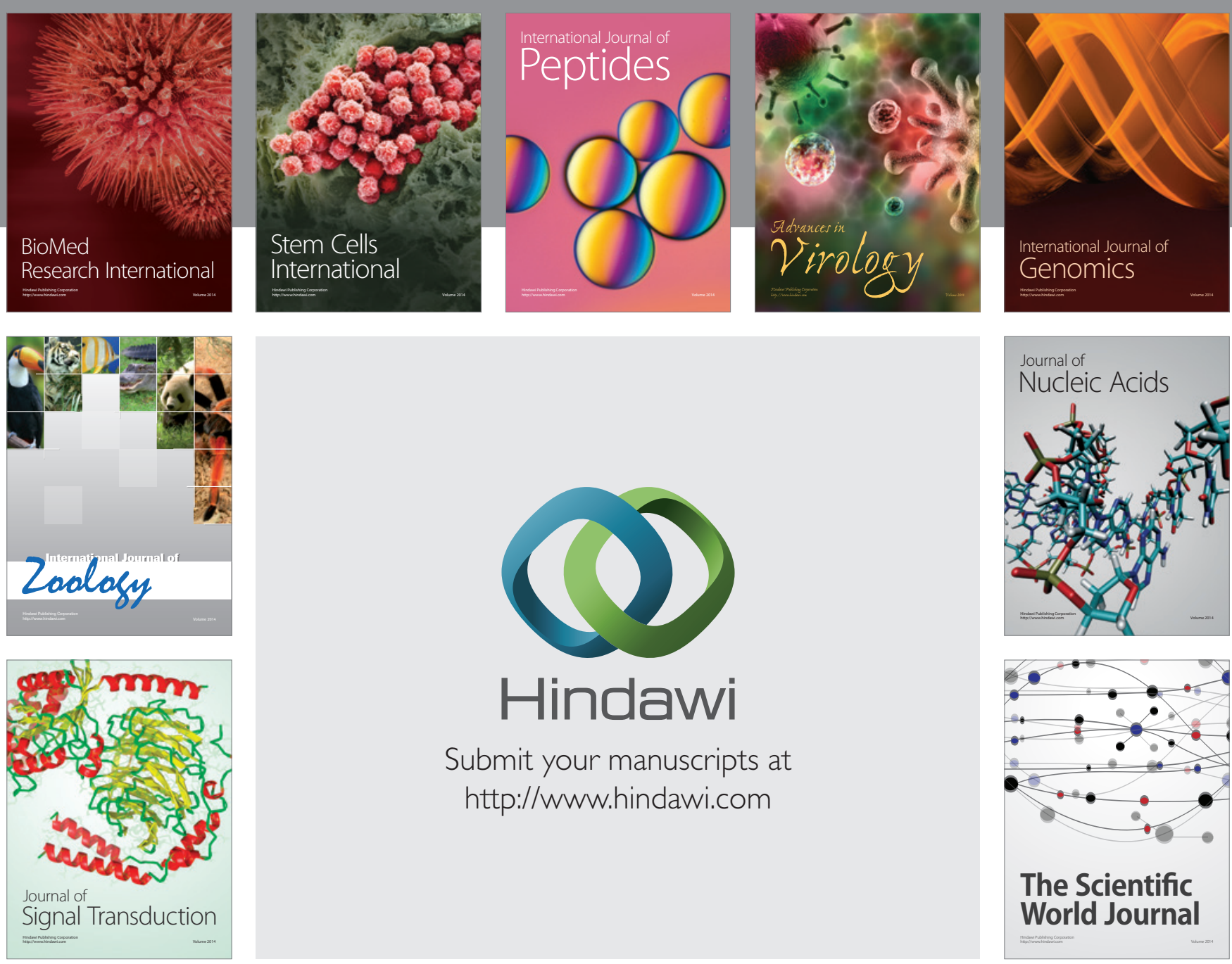

Submit your manuscripts at

http://www.hindawi.com
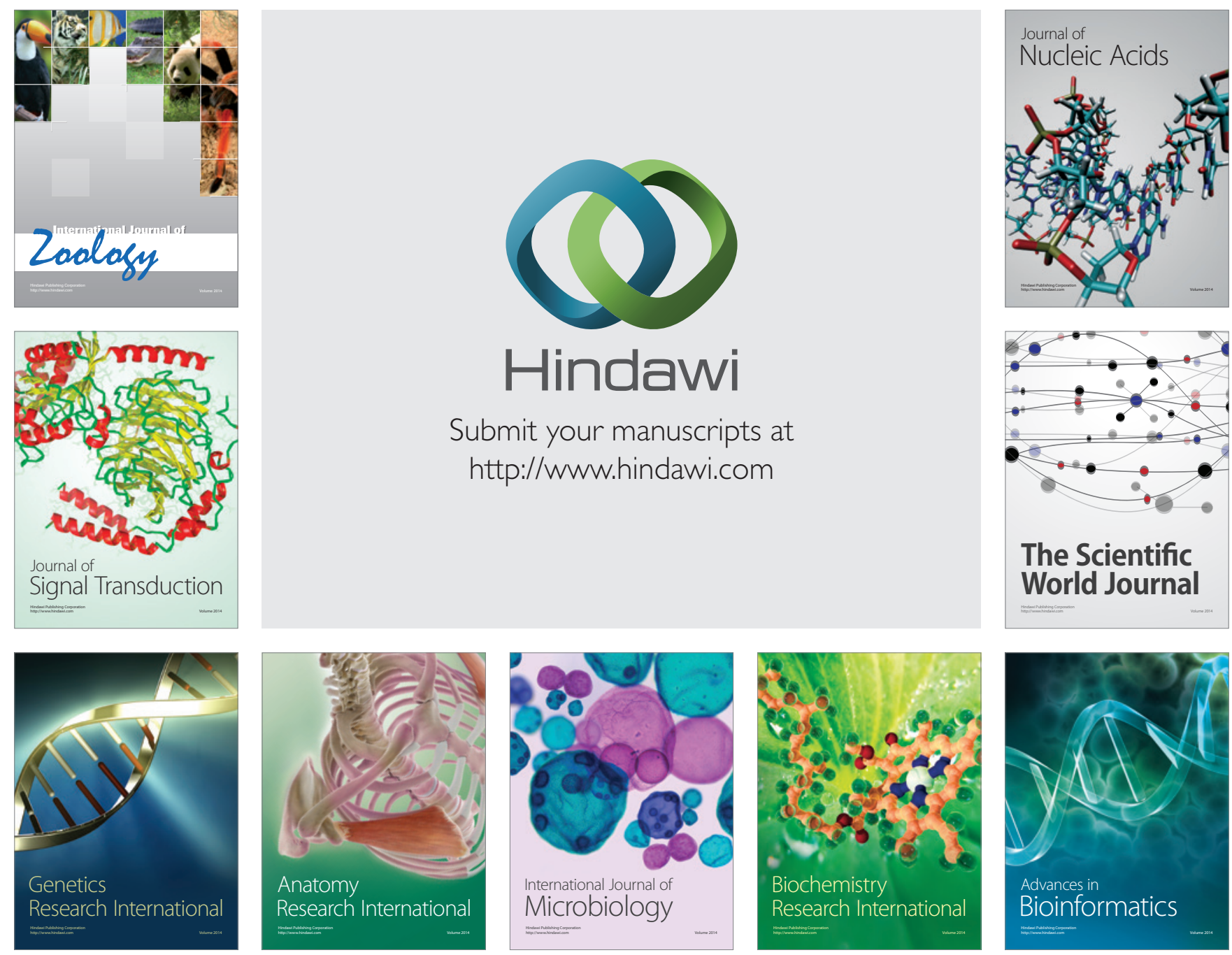

The Scientific World Journal
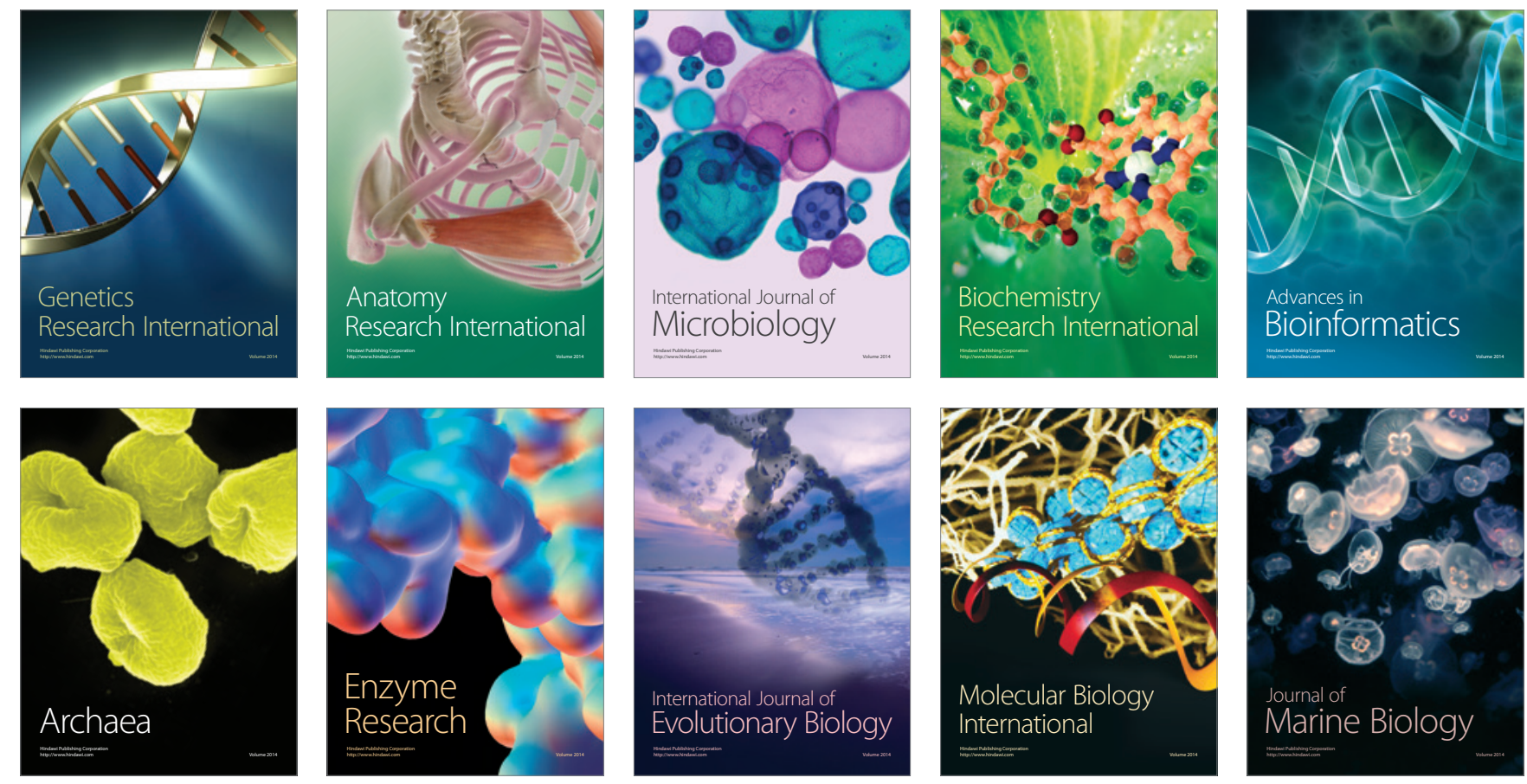